\title{
Effect of Sampling Amounts on Apparent Density of Metallic Powder*
}

\author{
Jian-Ping Dai**, Xi-Wen Lai***
}

\begin{abstract}
Influential factor was investigated during determining apparent density. The difference of apparent densities were obtained from different sampling amounts of powder. Authors were able to explain this phenomenon by means of the potential energy of powder particles from funnel to cup of the apparatus and the tapped powder in the cup because of striking action of falling powder particles overmuch to the cup.
\end{abstract}

(Received May 13, 1983)

\section{Introduction}

It is known that the powder metallurgy is still a new one of the metallurgical processes. With its wide development, the powder metallurgy is progressively obtaining a substantial theoretical basis.

It is also known well that the apparent density ${ }^{1 \sim 4)}$ of metallic powder is not only one of the basic concepts of powder metallurgy but also a very important physical characteristic which we often come across and make use of. The particle size, particle shape, flowability and compactibility of powder compacts can be approximately known in accordance with the data relative to the apparent density of metallic powder.

In order to substantiate the basic problem of powder metallurgy, results of the research, that is the method of analysis and the data from test are shown in this article for reference. Namely the object of this study is to know how the apparent density of metallic powder is affected by the amount and the flow condition of the same kind of metallic powder. The purpose of this article is only offering a few commonplace remarks by way of data so that others may come up with valuable opinions. So any suggestion and criticism are welcomed.

\section{Experimental Methods}

A, The apparatus for the test is shown in Fig. 1 and Photo. 1.

B, Samples: 5 samples of same kind of Höganäs's ore reduced iron powder and Chinese atomized copper powder as shown Photo. 2 and 3. Sampling amount of each was 80, 110, 140, 170, $200 \mathrm{~g}$ and 140, 170, 200, 230, $260 \mathrm{~g}$.

$\mathrm{C}$, Testing methods: Cooling the iron powder samples to ambient temperature after drying. Then pouring them into the funnel separately by the conventional method. The next operation had following two methods as shown in Fig. 2. Namely one of them, making powder down to the

\footnotetext{
* Manuscript received May 13, 1983.

** Tian Qiao First Works of Powder Metallurgy.

*** Central Iron \& Steel Research Institute, Beijing, The People's Republic of China.
} 


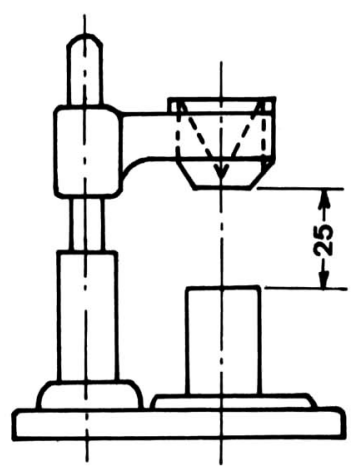

Apparatus

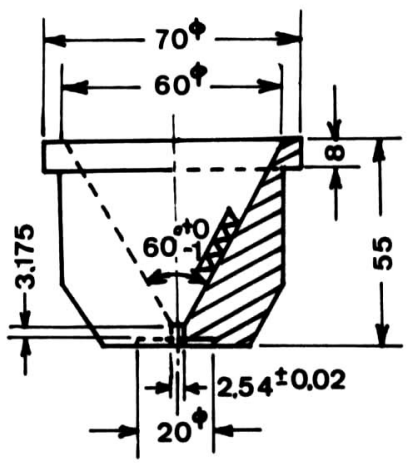

Funnel

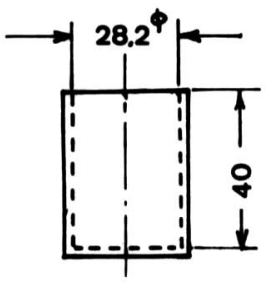

\section{$25 \mathrm{~cm}^{3}$}

Cylindrical cup

Fig. 1 Apparatus of determination of the apparent density of metallic powders.

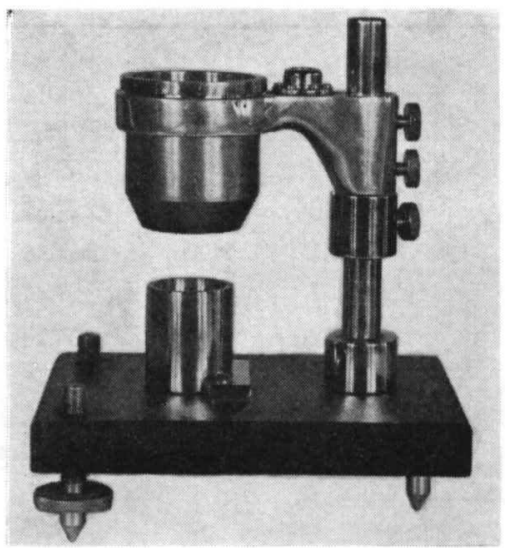

Photo. 1 Apparatus of determination of the apparent density of metallic powders.

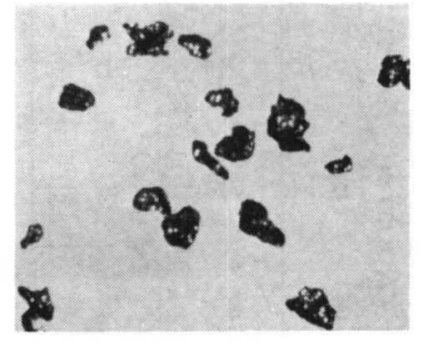

Photo. 2 Microstructure of iron powder used in the experiment. $\times 100$

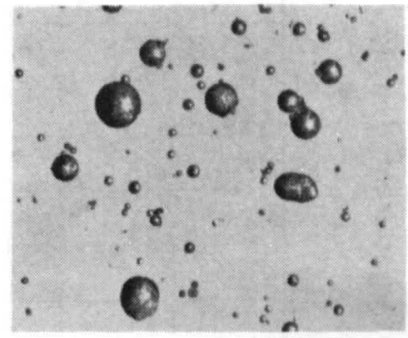

Photo. 3 Mcirostructure of copper powder used in the experiment. $\times 58$

center of cylindrical cup until all the powders are poured into the cylindrical cup. On the other of them, the falling powders are stopped as soon as the powder flows over the cup as described in the standards. A straight edge should used to level the surface of the powder in cylindrical cup, and meanwhile, tapping the cylindrical cup. Before weighing, this must be repeated several times. The accuracy of weighing is at $0.001 \mathrm{~g}$. This test should be done 3 to 5 times then the average value would be got. The tolerance of each test must be less than $0.03 \mathrm{~g} / \mathrm{cm}^{3}$.

\section{Experimental Results}

Results of the test works are as follows. Table 1 is apparent densities of iron powder samples 


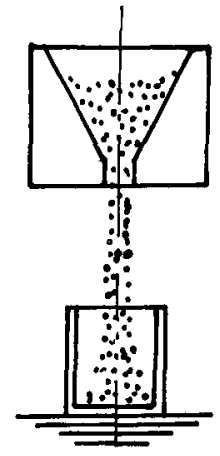

flows into

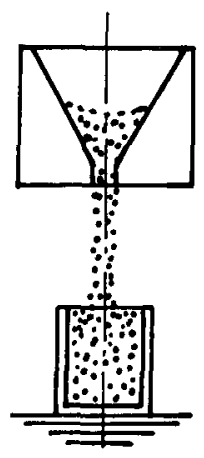

completely fills

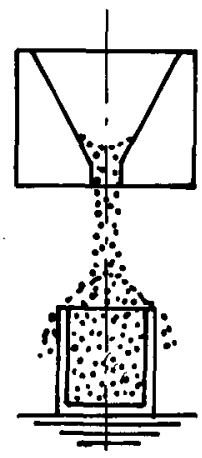

flows over

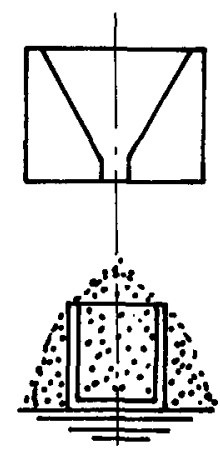

all flows

Fig. 2 Schematic view of test operation on the apparent density.

Table 1 Apparent densities of iron powder.

\begin{tabular}{|c|c|c|c|c|}
\hline \multirow{2}{*}{ Iron powder } & \multirow{2}{*}{$\begin{array}{l}\text { Sampling } \\
\text { weight }(\mathrm{g})\end{array}$} & \multirow{2}{*}{$\begin{array}{l}\text { Sampling } \\
\text { volume }\left(\mathrm{cm}^{3}\right)\end{array}$} & \multicolumn{2}{|c|}{ Average of apparent density $\left(\mathrm{g} / \mathrm{cm}^{3}\right)$} \\
\hline & & & $\begin{array}{l}\text { (a) Untill all amount } \\
\text { of powder flows }\end{array}$ & $\begin{array}{l}\text { (b) Untill powder flows } \\
\text { over the cup }\end{array}$ \\
\hline \multirow{5}{*}{$\begin{array}{l}\text { Höganäs } \\
\text { SC } 100 \cdot 26\end{array}$} & 80 & about 29 & 2.7406 & 2.7097 \\
\hline & 110 & about 40 & 2.7561 & 2.7234 \\
\hline & 140 & about 51 & 2.7638 & 2.7302 \\
\hline & 170 & about 61 & 2.7684 & 2.7315 \\
\hline & 200 & about 72 & 2.7710 & 2.7382 \\
\hline
\end{tabular}

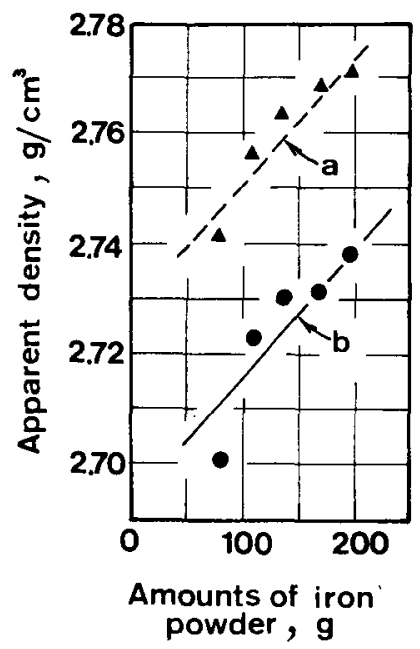

Fig. 3 Effects of amounts of iron powder on the apparent density.

a: untill all amounts of powder flows

b: untill powder flwos over the cup

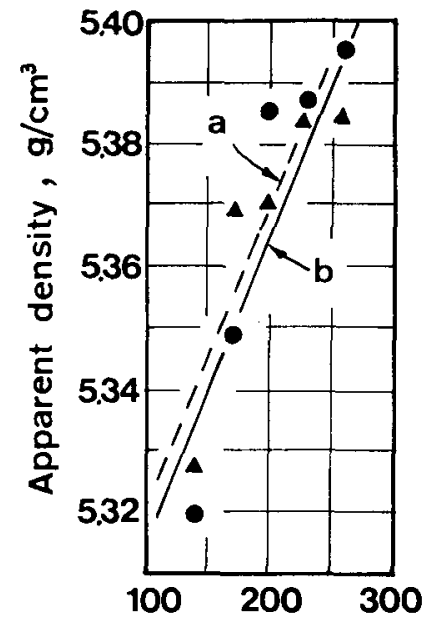

Amounts of copper powder, $\mathbf{g}$

Fig. 4 Effects of amounts of copper powder on the apparent density.

a: untill all amounts of powder flows

b: untill powder flows over the cup

when the amount of powder and the operation of powder flowing were changed. They increase with increase of the amount of powder, whether the powder in the funnel was stopped when it flows all or flows over the cup. But it is evident that the data of (b) obtained at the powder flowing over the cup are less than the data of (a) obtained at the all powder flowing as shown in Fig. 3. 
Table 2 Apparent densities of atomized copper powder.

\begin{tabular}{|c|c|c|c|c|}
\hline \multirow{2}{*}{ Copper powder } & \multirow{2}{*}{$\begin{array}{l}\text { Sampling } \\
\text { weight }(\mathrm{g})\end{array}$} & \multirow{2}{*}{$\begin{array}{l}\text { Sampling } \\
\text { volume }\left(\mathrm{cm}^{3}\right)\end{array}$} & \multicolumn{2}{|c|}{ Average of apparent density $\left(\mathrm{g} / \mathrm{cm}^{3}\right)$} \\
\hline & & & $\begin{array}{l}\text { (a) Untill all amount } \\
\text { of powder flows }\end{array}$ & $\begin{array}{l}\text { (b) Untill powder flows } \\
\text { over the cup }\end{array}$ \\
\hline \multirow{5}{*}{ Chinese } & 140 & about 26 & 5.3195 & 5.3271 \\
\hline & 170 & about 32 & 5.3495 & 5.3692 \\
\hline & 200 & about 37 & 5.3863 & 5.3696 \\
\hline & 230 & about 43 & 5.3866 & 5.3839 \\
\hline & 260 & about 48 & 5.3964 & 5.3840 \\
\hline
\end{tabular}

Table 2 and Fig. 4 are apparent densities of copper powder. These datas show the same tendency as the aboves. However, all the apparent densities of the copper powder by atomization show little difference each other due to a good packing ability of spherical powder shape. Morphology of the iron and copper powders are shown in Photo. 2 and 3.

\section{N Discussions}

Why will the apparent density of metallic powder increase with the increase of the amount of sample? The reasons are assumed as follows:

First, let's suppose, for $110 \mathrm{~g}$ of iron powder, the initiative centre of gravity is at $\mathrm{B}$, where the height ịs $h$ (Fig. 5).

On the analogy of this, for $140 \mathrm{~g}$ metallic powder, the initiative centre of gravity should be at A with the height $h+\Delta h$, where $h+\Delta h>h$. There are two kinds of force which act on them, namely gravities $P_{B}$ and $P_{A}$ and frictions between particles or between particles and the wall of funnel.

When M110 stands for the mass of $110 \mathrm{~g}$ metallic powder, its average speed of traveling to the position C should be V110. For $140 \mathrm{~g}$ metallic powder, we could relevantly get M140 and V140. If we regard the friction as a negligible quantity, by the knowledge of mechanics we know as follow.

$$
\mathrm{V} 140>\mathrm{V} 110 ; \mathrm{M} 140=\mathrm{M} 110 \text { or } \frac{1}{2}(\mathrm{M} 140) \cdot(\mathrm{V} 140)^{2}>\frac{1}{2}(\mathrm{M} 110) \cdot(\mathrm{V} 110)^{2}
$$

It shows us when M140 arrive C, its kinetic energy is bigger than the kinetic energy of M110 at its arrival of $\mathrm{C}$. So we could say that the apparent density of metallic powder increases with the increase of kinetic energy which is produced when the metallic powder move into C, conversely, the apparent density of metallic powder decreases with the decrease of kinetic energy which is produced when the metallic powder move into $\mathrm{C}$. Then in accorance with the law of conservation of energy,

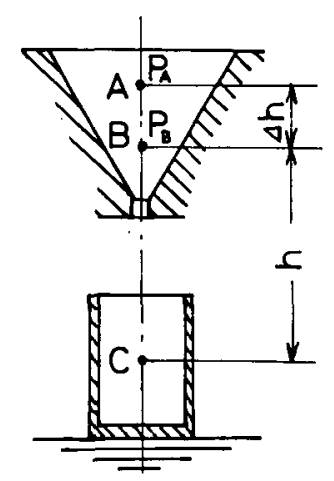

Fig. 5 Schematic representation of powder flow from funnel into cylindrical cup. 
the conclusion is that the apparent density of metallic powder depend on the initially given potential energy. But be sure to keep in mind that this conclusion is got under the case without any friction.

When we take the friction into consideration, what will be the result?

It is known when either the particle size decreases, number of particals increases or particle shape becomes more complex, the friction will increase, while the value of traveling speed of powder will become lower and lower. When the coefficient of friction is big enough, V140 and V110 equal to zero. It shows that only when the flow of metallic powder is stopped, the potential energy which affects the metallic powder will not act to the powder flow. In another words, the faster the flow is, the more greatly the potential energy affects to the powder flow. Therefore, if the flow of the spherical copper powder is fast enough, the potential energy affecting to the powder flow is big enough too. Namely, it should be explained with the aboves that the increasing-rate of apparent density of the spherical copper powder for its amount was higher than that of the irregular iron powder as shown in Fig. 3 and 4.

Next, it must be also considered that the apparent density of powder in the cylindrical cup is increased by the effect of striking action of powder flow after the powder has flown over the cup, and the striking action is found out by compareing with the data of (a) and (b) in Table 1, 2 or Fig. 3, 4. That is, the apparent density of (a) is more than that of (b) in the same sampling weight of powder. Therefore, the effect of striking action of powder flow on the apparent density of powder is able to be recongnized clearly.

In this connection, the matter that the difference between apparent densities of (a) and (b) shown in Table 2 or Fig. 4 on the spherical copper powder was less than that shown in Table 1 or Fig. 3 on the irregular iron powder should be explained by a good packing-ability of the spherical copper powder.

\section{Conclusions}

The combination of the above results and discussions could give us following essential ideas on apparent density of metallic powder:

(1) The sampling amount of metallic powder is effective on an accurate apparent density of the powder with the prescribed apparatus.

(2) A limitation of the sampling amount of powder and an operation of stopping flow of powder when it flows over the cylindrical cup as described in the international standards are accuracy for determination of apparent density of metallic powder.

(3) Both the potential energy (momentum $\frac{1}{2} M V^{2}$ ) and the striking action of powder flow affect on the data of apparent density. The apparent density increases with increase of the amount of powder, whether the powder in the funnel is stopped when it flows over the cylindrical cup or flows all.

(4) The error is negligible under the sampling condition of international standard.

Acknowledgment: Author wishes to thank professor Dr. T. Watanabe and his assistant Dr. O. Iwatsu of Department of Metallurgical Engineering, School of Science and Engineering WASEDA University and Mr. Xun-lie Yang of Central Iron \& Steel Research Institute in Beijing for useful opinions in this article and favors on the translation of it into English. 


\section{Reference}

1) Standard GB 1479-79 method for determining apparent density of iron powder, Ministry of Machine Industry, The People's Republic of China.

2) ISO 3923/1; Metallic powders--Determination of apparent density- Part 1: Funnel method (1979).

3) JIS Z 2504; Method for Determination of Apparent Density of Metal Powder, (1966).

4) S. Wakabayashi and T. Watanabe; Revised Edition of Powder Metallurgy, (1968) p. 48.

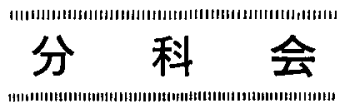

\section{抄録}

\section{第58回超硬合金分科会研究発表抄録}

\author{
日 時：昭和58年12月 7 日（水） \\ 会 場 : 学上会尔館 \\ 資 料: No. $214 \sim 216$
}

\section{資料 No. 214}

$「 \mathrm{TiC}$ 基サーメットの強度に及ぼす $\mathrm{TiC}, \mathrm{TiN}$ 化学蒸着被覆の影響」

冨士ダイス侏 土屋信次郎，寺田 修

主として $\mathrm{TiC}-\mathrm{Mo}_{2} \mathrm{C}-\mathrm{Ni}(\mathrm{Co})$ 合金の抗折力に及ぼす $\mathrm{TiC}, \mathrm{TiN}$ 化学蒸着被覆の影響とそれらに生じる被覆屬 組織を調べ以下の諸結果を得た。

(1) 化学蒸着偟り $\mathrm{TiC} や \mathrm{TiN}$ を被覆した $\mathrm{TiC}-\mathrm{Mo}_{2} \mathrm{C}$ $\mathrm{Ni}(\mathrm{Co})$ 合金の強度は，いずれの場合も被㠅層の厚み 増加と共に低下した。

（2）強度低下の程度は，TiC，TiNいずれの被覆の場合む 結合相が Co の合金に比べて Ni 合金の方が著しかっ た.

（3）結合相が Ni の合金で強度低下が大きいのは，主と して母材中の Ni が化学洆着中に被覆層中へ搪散流入 する為，界面份ってミクロポアーが形成され，その 結果, 被膜厚さとポア一形成領域の和が破壊時さ裂長 さとして作用することに起团すると推定された。

（4）被覆層中へ拡散流入した $\mathrm{Ni}$ は, $\mathrm{Ni}_{3} \mathrm{Ti}, \mathrm{NiTi}$ 相と して取込まれることが判った。

\section{資料 No. 215}

$\lceil\alpha, \beta$ 二相混合組織を持つサイアロンの組織と 特性」

三菱金属侏 杉沢泰次郎, 安島 辰郎, 西垣 賢一 $\mathrm{Si}_{3} \mathrm{~N}_{4}-\mathrm{AlN}-\mathrm{Y}_{2} \mathrm{O}_{3}$ 采で窒素零囲気の常圧焼結法により $\alpha, \beta$ 二相混合組織を持つサイアロン諉結体が得られた。 混合組成と焼結体の $\alpha / \beta$ 相の比率, 強度特性, 組織上 の特徵，焼結体の組成に関し以下の結果を得た。

(1) 烓結体 $\alpha / \beta$ 相比は $\mathrm{Y}_{2} \mathrm{O}_{3} 5 \mathrm{wt} \%$ の組成において $\mathrm{AlN}$ の量変化させた時, $\mathrm{Y}_{2} \mathrm{O}_{3}$ と AIN のモル比が $1 ： 9$ で最大となり $\alpha$ 相率は約 $50 \%$ であった. 又 $\mathrm{Y}_{2} \mathrm{O}_{3}$ $7.5 \mathrm{wt} \%$ の組成では $\alpha$ 相量は77\%まで增加した（2) 焼結体の硬度は $\alpha$ サイアロン相の増加ととむに上昇し, 最大值 $940 H_{R A}$ を示した。（3）焼結体破面の SEM 観 察による $\alpha, \beta$ サイアロン佬結体の組織は単相の $\beta$ サイ アロンに比べて等方的な粒が多く瀻維状に成長した粒が 少ない. (4) $\alpha$ 相比の多かった $\mathrm{Y}_{2} \mathrm{O}_{3} 7.5 \mathrm{wt} \%$ 組成の 燒結体を分析電影を用いて定量し， $\alpha$ 相 $之 \beta$ 相の組成 を各々 $\mathrm{Y}_{0.6} \mathrm{~S}_{10} \mathrm{Al}_{2} \mathrm{O}_{0.3} \mathrm{~N}_{15.6}, \mathrm{Si}_{5} \mathrm{AlON}_{7}$ のように決定し た. 又 $\alpha$ 相中の $\mathrm{Y}$ 量は配合量の約 3 分の 1 程度であり, 残りのYは結合相などとして存在していると推定された。

資料 No. 216

「放電加工によるセラミックスの加工」

住友電気工業称 土井 良彦, 飛岡 正明

セラミックスの放電加工性について, 非導電性セラミ ックスに, 種々の量の導電性分散粒子を添加した試料を 作成し，検討安行った．試料の電気伝導度 $\sigma$ が $1 \times 10^{-3}$ $\Omega^{-1} \mathrm{~cm}^{-1}$ 以上あれば，放電加工が可能であるととがわか った. 又試料の電気伝導度は, 混合則にのらないとと, 焼結助剤の量にあ大きく左右されることなどから，試料 が導電性を得るのは, 導電性の分散精子相が接触し合う ことによるのではなく，導電性分散粒子の一部がマトリ ックスである非導電性セラミックスおよび焼結助剂と反 応し, マトリックスの周囲に導電性の粒界相が形成され, この粒界相が連続することによるのではないかと考えら れた。 